\title{
NATURAL GRASSLANDS AS BASIS OF LIVESTOCK DEVELOPMENT IN HILLY- MOUNTAINOUS REGIONS OF CENTRAL SERBIA ${ }^{1}$
}

\author{
M. Stošić, D. Lazarević, B. Dinić, D.Terzić, A. Simić
}

Content: Review of results obtained in researches carried out over period of several years is presented in this paper. The importance of natural grasslands for Central Serbia which occupy $38 \%$ of the agricultural lands is pointed out. Yields on natural grasslands are approx. 1,9 and on pastures $0,4 \mathrm{t} / \mathrm{ha}$ of dry matter. Through application of mineral fertilizers production is increased considerably and 5-8 t/ha of dry matter is realized. In order to achieve production, ecological and economical effect it is important that ratios and quantities of nutrients are adjusted to each plant association. In conditions of Central Serbia the situation should be as follows: $\mathrm{N} 40-120 \mathrm{~kg} / \mathrm{ha}, \mathrm{P}_{2} \mathrm{O}_{5}$ and $\mathrm{K}_{2} \mathrm{O}$ per $30-45 \mathrm{~kg} / \mathrm{ha}$. Total amount of fertilizer should be applied in spring before the start of vegetation. Use of nitrogen nutrient has no effect. Season as factor in formation of yield is pointed out. However, it can be influenced slightly by time of first cut or beginning of grazing.

Key words: natural grasslands, production dynamics, fertilization, floristic composition

\section{Introduction}

Natural grasslands in Serbia present considerable source of voluminous livestock feed and also are considered as important component of the environment, especially from the aspect of protection of soil from erosion and preservation of biodiversity. Distribution of grasslands in the region is unequal but there are certain regularities: with the increase of altitude also the grassland areas increase, especially their share in the structure of soil utilized in agriculture.

For development of livestock production in hilly-mountainous region grasslands are of paramount importance since they present major or single source of livestock feed. In low regions grasslands are of marginal importance since they are located on border soil types and have great competition in intensive field production of livestock feeds. Practically, only grasslands on marshy terrains in Vojvodina have certain commercial/economical value in sheep production.

Central part of Serbia is mainly of hilly-mountainous character in its orrographic characteristics. Therefore, natural grasslands in this region are of great importance. This is also illustrated by data relating to their share in agricultural land of 38\% (approx. 17\% meadows and $21 \%$ pastures), total area under grasslands as form of production of livestock feed is approx. 1.260.000 ha. In Central Serbia, in 56 municipalities of total of 101 (without Belgrade) share of grasslands in agricultural area exceeds $20 \%$, and in 42 municipalities grasslands participate with over $40 \%$. Based on previously mentioned data it can be concluded that in half of the municipalities natural grasslands are the most present method of plant production.

Current condition of natural grasslands in this region in no way confirms previously stated facts and statement of their great importance for future economical development. We are talking about predominantly non utilized potentials of this nature's resource. In present period areas are mainly neglected with low biological production (1,9 t/ha of dry matter on meadows and $0.4 \mathrm{t} / \mathrm{ha}$ on pastures). Somewhat better condition is recorded in western parts of mentioned region. In central and especially eastern parts these areas are not only neglected but abandoned which is in strong correlation with depopulation. Eastern part of Central Serbia, from Macedonian border to river Danube is practically without population/inhabitants and without domestic animals.

Not commenting the state demographic and agricultural policy, which is in no way topic of this paper, we would like to point out the possibility of organization of rational cattle, sheep and goat breeding system on these vast areas of natural grassland territory in hilly-mountainous region of Central Serbia. Main

1 Review paper supported by the Ministry of Science and Environment Protection, Project no. TR6872B - Revijalni rad je finansiran od strane Ministarstva za nauku i zaštitu životne sredine Projektom broj: TR6872B

2 Prof. Dr Milorad Stošić,scinetific advisor, Dr Dragi Lazarević, scinetific advisor, Dr Bora Dinić, scinetific advisor, Mr Dragan Terzić, research asistant, Agriculture Research Institute Serbia, Center for Forage Crops Kruševac, Mr Aleksandar Simić, asistant, Agriculture faculty Zemun 
limiting factor for such rapid increase of livestock production is relative small size of land owned by people who no longer live on these terrains. Therefore it would be of great importance if the issue of utilization of agricultural land could be regulated more efficiently through adequate legislative tools and by credit policy small number of large agricultural producers be stimulated for meat production - cattle, sheep and goats.

What are the possibilities for improvement of livestock production based on natural grasslands will be illustrated by results obtained from numerous researches carried out over several years.

\section{Research results}

Intensive researches of the possibilities and methods of improvement of livestock feed production on natural grasslands in Serbia have been initiated during fifties of the last (twentieth) century. Majority of trials and the territory mostly covered by trials were carried out by the Centre for forage crops in Kruševac, Faculty of agriculture in Zemun and Institute for Animal Husbandry, Belgrade-Zemun. These institutions employed the best research and scientific experts capable for investigating mentioned issues: improvement of production, conservation/preservation of livestock feed and its utilization. Majority of researches was realized through projects financed by the Ministry of Science of the Republic of Serbia. During the period of regional organization (seventies and eighties of the previous century) such researches were also financed by regional government authorities in charge of scientific activities. Also, commercial firms and organizations (especially factories producing mineral fertilizers) and their associations (Association of producers of mineral fertilizers Agrohemija) were also interested and supported research projects in this field.

Published research results showed that in previous period all aspects relating to improvement of natural grasslands had been taken into consideration. Researches included the issue of the effect of fertilization on yield, floristic and chemical composition of grass mixture, influence of prolonged effect of fertilization, time of preparation, ratio of nutrient and quantity, cutting, method of conservation/preservation of biomass from natural grasslands, etc. However, not all fields were treated in the same way. The majority of research papers belong to the group studying the effect of fertilization, and the least papers are treating the conservation/preservation and utilization.

\section{Effect of fertilization on yield}

Official statistical data state that average yield realized on natural grassland is $1,9 \mathrm{t} / \mathrm{ha}$ and on pastures $0,4 \mathrm{t} / \mathrm{ha}$ of dry matter. In numerous published research results stated average yield on grassland is 2,1 and on pasture $0,7 \mathrm{t} / \mathrm{ha}$. Differences result from the fact that for such trials parcels are chosen with characteristics of soil and flora that are as unified as possible.

Initiator/creator of the research of agronomy knowledge and studying of grasslands in Serbia is professor Vlastimir Đorđević from the Faculty of Agriculture in Zemun. Together with him and subsequently this work was continued by numerous associates from already mentioned institutions.

Characteristic of initial research of the effect of fertilization on changes occurring on natural grasslands, primarily through use of mineral fertilizers, is application of equal quantities of nitrogen, phosphorus and potassium nutrients. Đorđević and Mijatović (1965), in their study of changes in association Nardetum strictae concluded that introduction of $100 \mathrm{~kg} / \mathrm{ha} \mathrm{N}, \mathrm{P}$ and $\mathrm{K}$ had tripled the yield and that combinations of only two nutrients had no significant effect. Đorđević and Radojević (1968) applied NPK fertilizer in equal ratio of nutrients on Nardetum strictae pasture starting with 200 to $600 \mathrm{~kg} / \mathrm{ha}$ and obtained twice as high yields compared to control, but differences between investigated treatments were not so distinct (from 2,5 to 3,7 t/ha DM). Mijatovic et al. (1968) investigated the changes occurring on pasture Agrostietum vulgaris and applied same or different shares of NPK nutrients on different levels. Simultaneous increase of quantities from 30 to 60 and $90 \mathrm{~kg} / \mathrm{ha}$ of each nutrient influenced constant increase of yield $(2,3-3,3-4,2$ $\mathrm{t} / \mathrm{ha} \mathrm{DM})$. However, increase of quantities of $\mathrm{N}$ and maintaining of lowest quantities of $\mathrm{P}$ and $\mathrm{K}$ resulted in the same yield as when quantities of $\mathrm{P}$ and $\mathrm{K}$ were higher. Authors concluded that from the economical aspect the most favourable ratio was 3:1:1. Jasna Pavešić-Popović, in her eleven year research of the association Chrysopogonetum grylli obtained results confirming that combinations of two nutrients increased the yield but only in comparison to unfertilized areas, but only treatments consisting of all three nutrients resulted in full contribution and that nitrogen had the greatest influence. Increased quantities of P and K didn't increase the yield. Stošić (1972) studied changes occurring on grassland Danthonietum calycinae on Sjenica-Pešter 
highlands and the author determined that increased quantities of $\mathrm{N}$ and same quantities of $\mathrm{P}$ and $\mathrm{K}$ constantly and significantly increased the yield, that increased quantities of phosphorus in some cases result in increased yield, but this was never the case with potassium. Stošić (1974) also determined, in his long research of association Danthonietum calycinae on mountain Goč, that combinations consisting of two nutrients (NP, $\mathrm{NK}, \mathrm{PK}$ ) effected the increase of yield in comparison to control and that the highest yield was recorded in treatment NP and the lowest in treatment PK. However, these increases, although statistically significant, had no economical importance. Author concluded that ration 3:1:1 (150:50:50) gave the best results. Lazarević et al. (2003) analyzed the results of research carried out over period of several years and on different locations and concluded that by increase of quantity of $\mathrm{N}(30-150 \mathrm{~kg} / \mathrm{ha})$ with quantities of $\mathrm{P}$ and $\mathrm{K}$ of $50-60 \mathrm{~kg} / \mathrm{ha}$ the greatest relative increase of yield on poorer grassland associations was achieved but that absolute increase was always significantly higher on more productive grasslands.

Application of mineral fertilizers in our conditions is not in harmonization with research results. Use of fertilizers is modest, and often incorrect. When they decide to use fertilizers on their grasslands producers often make serious mistakes: they apply only complex fertilizer with equal ratio of nutrients or only nitrogen fertilizer. Such practice will result in certain increase of yield but insufficient and with negative effect on rationalization of production. High efficiency of nitrogen fertilizer can not be achieved without the presence of phosphorus and potassium. Quantities of nitrogen must be adjusted to production potential of the grassland, and quantities of phosphorus and potassium should be above the amount carried out by the yield. Practically, in our conditions ratio of these three nutrients should be 3-4:1:1, and quantities the following: for nitrogen 40120 , phosphorus and potassium $30-45 \mathrm{~kg} / \mathrm{ha}$.

The recent analysis of the utilization of mineral fertilizers on grasslands of England and Wales suggests that average application of nitrogen is $65-135$, and of phosphorus and potassium $20-35 \mathrm{~kg} / \mathrm{ha}$ (Rath M. and Peel S., 2005).

\section{Effect of the time of fertilizer application on yields}

Opinions relating to time of application of mineral fertilizers are different. In initial stages of investigations relating to improvement of natural grasslands it was considered that phosphorus and potassium fertilizers should be applied in fall and nitrogen fertilizers in spring and in several repetitions. Not considering the organizational difficulties and increased human labour, such approach was acceptable when mineral fertilizers were present on the market as single nutrients. However, results of research of mineral fertilizers in form of single nutrients (KAN, super phosphate, potassium salts) showed no justification for such thesis. Mijatović and Jasna Pavešić-Popović (1972), in their seven year research on two plant associations determined that application of PK fertilizer in fall and $\mathrm{N}$ fertilizer in spring or application of all fertilizer types only in spring showed no differences in yield in association Chrysopogonetum grylli, and only few minor differences in favour of spring application of all fertilizers in case of association Agrostietum vulgaris. Situation changed when industrial producers of fertilizers started to produce complex mineral fertilizers containing all three nutrients, regardless of their ratio. In investigation carried out by Stošić et al.(1974) it was determined that spring application of complex fertilizer with equal share of all three nutrients had slight advantage, since yields compared to fall application were higher by $12,7 \%$ in average during three year period.

Stošić et al. (1996a, 1996b) investigated the effect of fertilizer application on natural grasslands of type Festuceto-Agrostietum on mountain Kopaonik $(1600 \mathrm{~m})$ and grassland of type Agrostietum vulgaris $(1000 \mathrm{~m})$ and determined that yield in the second cut was somewhat higher when fertilizer had been applied and with regular precipitation, which is often not the case in our conditions. Therefore, the authors concluded that application of nitrogen fertilizer on natural grasslands after the first cut in mountain region is not justified. They recommended that all planed quantities of fertilizer should be applied as early as possible in spring subsequent to melting of snow.

\section{Effect of fertilization on floristic changes}

Papers covering the field of improvement of natural grasslands without considering also the floristic composition and changes occurring as result of fertilization or utilization method are rare. In the majority of such papers phytocenological aspect of the research is only of auxiliary character although it represents the 
basis for understanding of the relation between diverse species. Botanists - phytocenologists are engaged in phytocenological researches in the narrow sense. Recently an overall phytocenological study of grasslands in Serbia was carried out which could be used as basis for future phytocenological investigations (Kojić et al. 2004). In order to study the production potential of grassland associations and direction of the changes occurring in them, it is usual to use floristic records obtained according to methods of the Swiss-French school (Braun-Blanquet). In further procedure, by measuring each species its weight share is determined and based on this data changes are analyzed and conclusions reached. It is important to point out that natural grasslands as subject of research are mainly secondary plant associations created after clearing of forests, in other words they are of anthropogenic character. After clearing of forests soil is used for field production, mainly crop production, for certain period of time and then it is left. When soil is left unused after clearing of forest and after crop production self overgrowing of pioneer grass species occurs in first year and subsequently grasses of Poaceae family. In this way through progressive changes differentiated plant association is formed (Kojić et al.1995). Floristic composition depends on several circumstances: altitude, soil conditions, humidity, time and method of utilization. Phytocenology as scientific field/discipline has plant associations as main category, whereas in investigations of agronomical aspect of the same plant associations the term grassland type is used.

Basic floristic trait of our natural grasslands located in the forest zone is presence of numerous species, often not only over 100 but even over 200 species on very small area. From agronomical aspect they are classified in two families (Poaceae and Fabaceae) and group „remaining“ (weeds, herbaceous plants). Plants from this group, which are often referred to as weeds, contribute to the floristic diversity of grasslands regardless of the fact that many of them have great nutritive value. Classification to conditional and absolute weed plants is not considered in this research. On our grasslands, number of plant species from the family Poaceae is approx. 20, plant species belonging to family Fabaceae approx. 10, and remaining are «weed» species. Whether certain grassland has been exposed to improvement measures and what its general condition is can easily be recognized by its appearance: if it is rich association from the floristic aspect than it is neglected and non productive, if it is association with predominant presence of species from family of grasses than it is improved and correctly utilized grassland. Natural grasslands are source of bio diversity in hillymountainous region and their purpose in certain enclaves can be preservation of the gene fond and production of high quality food (Đorđević S. et al.,1997). Research results obtained in Serbia indicate rapid decrease of the number of species when melioration/improvement measures are undertaken, especially if mineral fertilizers are used. Radojević et al. (1980) investigated the productivity and floristic changes on grasslands Nardetum strictae on mountain Kopaonik and established that by application of increased quantities of NPK fertilizer with equal ratio of nutrients share of species from the family of grasses increased from 65 to $85 \%$, and presence of weed species decreased. Also, presence of species Nardus stricta decreased from 17,2 to $1,1 \%$. Stošić (1974) determined that of 54 species in association Danthonietum calycinae on mountain Goč after four year application of mineral fertilizers, total number of species was reduced to 13: one leguminous plant and three weed species in traces and 6 grass species making 99,2\% of biological production. Carriers of yield in this case were species Agrostis vulgarias and Festuca rubra. It was also determined that by increasing the quantity of nitrogen share of species Agrostis vulgaris also increased in relation to species Festuca rubra. When improvement measures are stopped grassland returns to its initial form: number of flowering plants increases and after several years the bushy vegetation begins to develop (Stošić et al.1999). By analysing results of research carried out over period of several years on many locations and plant associations Stošić et al. (1989) determined that grassland of type Festucetum rubrae on South Kučaj mountain transformed into type Festucetum pratensis, Danthonietum calycinae on Goč and Sjenica-Pešter highlands into Agrostietum vulgaris, Festuco rubrae-Cynosuretum cristati on Javor into Lolietum perenne and Festuco-Agrostietum on Kopaonik into Agrostietum vulgaris. Certain regularity can be registered based on results of this but also other researches: almost all types of grasslands in hilly-mountainous regions of central Serbia transform into Agrostietum vulgaris, Festucetum rubrae or their transitional forms, under effect of melioration measures. Therefore these two species have paramount importance in realization of yield and quality of livestock feed produced on natural grasslands. 
The effect of time of utilization on yield

Dynamics of accumulation of bio-mass on grasslands, especially on natural grasslands, is rather unequal and has seasonal character. This is result of biological traits of species on one hand and conditions of environment on the other (altitude, temperature, precipitation, soil traits, etc.). For natural grasslands in our conditions it is characteristic that in the first part of vegetation period maximum of production is achieved, followed by significant decrease. In the second part of July and throughout August vegetation almost stops. In September it is restored but intensity of the yield formation is very low.

Seasonal character of production on natural grasslands is great limiting factor of even and stable livestock production. Possibility to reduce the negative effect of season factor is small and in hillymountainous region introduction of seeded/artificial grasslands with mixtures of different maturation time and sped of regeneration could partially reduce problems.

Few studies of this problem carried out in Serbia have insufficiently explained the changes occurring in forming of biological production on natural or artificial grasslands. Studying the character of changes on natural grasslands of mountain Kopaonik on 1000 and $1600 \mathrm{~m}$ above sea level, Stošić et al. (1996a, 1996b) have obtained results that by different times of first cut $(40,47,54,61,68$ and 75 from the beginning of vegetation and second cut after regeneration of 42 days) yield is increased in first cut significantly (almost linearly), and decreases in the same way in the second cut. Total yield on both altitudes also increased when the first cut had been delayed. Lazarević (199....) carried out the most abundant research of the dynamics of production. Studying the reaction of association Danthonietum calycinae (Kopaonik,1200 m) on different systems of utilization the author determined that the highest yield was realized in rotational grazing of sheep (4,3-5,02 t/ha of absolutely dry matter), somewhat lower yield in case of continuous grazing $(3,87-4,96)$, and the lowest in case of cutting $(2,95-3,76 \mathrm{t} / \mathrm{ha})$. In these researches yield increased with delaying of the utilization. The greatest daily accumulation was achieved in the beginning of July (approx. $65 \mathrm{~kg} / \mathrm{ha}$ ).

\section{Conclusion}

Natural grasslands in Central Serbia occupy $38 \%$ of agricultural land and in 42 municipalities (of 101) natural grasslands make over $40 \%$. They are main source of livestock feed in hilly-mountainous region. Low productivity $(0,4 \mathrm{t} / \mathrm{ha}$ of dry matter on pastures and $1,9 \mathrm{t} / \mathrm{ha}$ on meadows $)$ is consequence of absence of improvement measures and determined high potentials are illustration of the way in which natural resources are not used.

Improvement of natural grasslands is achieved through application of mineral fertilizers. Numerous researches confirmed that yields over 5-8 t/ha can be realized. Of great ecological and economical importance is to adjust the quantities and ratio of nutrients to each plant association. Ratios of NPK nutrient should be approx. 3-4:1:1, and quantities 40-120 kg/ha of nitrogen and 30-45 kg/ha each of phosphorus and potassium $\left(\mathrm{P}_{2} \mathrm{O}_{5}\right.$ and $\left.\mathrm{K}_{2} \mathrm{O}\right)$. It is justified to use these amounts of fertilizer once in spring before begin of vegetation. Use of nitrogen nutrients especially on altitudes over $500 \mathrm{~m}$ above sea level has no effect.

Floristic richness of natural grasslands is result of high share of numerous species from different families and genders, whereas the share of species from families Poaceae and Fabaceae is low. Mineral fertilizers reduce significantly the share of weed species and force the development of grasses. Tendency that diverse grass associations get transformed into Agrostietum vulgaris, Festucetum rubrae or their transitional forms is apparent.

Forming of yield during vegetation period is very uneven. The highest daily production is realized by the end of May and start of June, followed by great decrease and cessation of vegetation in the second part of July and in August. Possibilities for change of dynamics are scarce. 


\title{
PRIRODNI TRAVNJACI KAO OSNOVA RAZVOJA STOČARSTVA U BRDSKO- PLANINSKOM PODRUČJU CENTRALNE SRBIJE
}

\author{
M. Stošić, D. Lazarević, B. Dinić, D. Terzić, A. Simić
}

Rezime

Prirodni travnjaci su vrlo značajan izvor stočne hrane u Srbiji, posebno u brdsko-planinskom području centralnog dela. Ovde livade i pašnjaci zauzimaju oko 1.260 .000 ha i čine $38 \%$ poljoprivredne površine. Od 101 opštine, gotovo u jednoj polovini oni učestvuju sa preko $40 \%$ u poljoprivrednoj površini. Statistika evidentira prinose na livadama 1,9 a na pašnjacima 0,4 t/ha suve materije.

Rezultati velikog broja istraživanja u periodu od 50 godina pokazuju da se unapređenje travnjaka najbrže ostvaruje primenom mineralnih đubriva. Utvrđeno je da je najpovoljniji odnos NPK hraniva 3-4:1:1, a količine za N 40-120, a za $\mathrm{P}_{2} \mathrm{O}_{5}$ i $\mathrm{K}_{2} \mathrm{O}$ po 30-45 kg/ha. Proizvodni potencijali iznose 3-10 t/ha suve materije. Utvđeno je da sve količine đubriva treba upotrebiti rano u proleće, pre kretanja vegetacije. Prihranjivanje, pogotovu preko $500 \mathrm{~m}$ nadmorske visine, ne utiče na promene prinosa.

Neđubreni travnjaci su floristički raznovrsni i vrlo bogati vrstama (i preko 200). Kod popravljenih travnjaka broj vrsta opada na oko 20 i manje. Opšta je tendencija da se svi tipovi travnjaka transformišu u Agrostietum vulgaris, Festucetum rubrae ili njihove prelazne forme. Kada đubrenje prestane travna zajednica se postepeno vraća u ishodnu formu.

Formiranje prinosa ima izražen sezonski karakter. Najveća dnevna produkcija je krajem maja i početkom juna. U drugoj polovini jula i u avgustu vegetacija uglavnom miruje (prestaje). Ukoliko je nadmorska visina veća, kosidbu treba odlagati ali ne posle faze punog metlanja (klasanja) najzastupljenijih vrsta.

\section{References}

1. ĐORĐEVIĆ V., MIJATOVIĆ M.(1965):Effect of Fertilization on the Productivity, Botanical composition and Quality of Haz on Nardetum strictae Meadow.Journal for Scinetific Agricultural Research,vol.18,No 59,3-21

2. ĐORĐEVIĆ V., RADOJEVIĆ D.(1968):Uticaj količina kompletnog đubrenja mineralnim đubrivima $(\mathrm{NPK}) \mathrm{u}$ istomodnosu hraniva na produktivnost i kvalitet pašnjaka tipa Nardetum strictae, Zbornik naučnih radova,sv.II i III, Kruševac,53-64

3. ĐORĐEVIĆ-MILOŠEVIĆ SUZANA, MRFAT-VUKELIĆ SLAVICA, RAKOČEVIĆ MIROSLAVA, ZAKONOVIĆ M.(1997):Prirodni travnjaci brdsko-planinskog područja Jugoslavije kao potencijal za proizvodnju biološki visoko vredne hrane.Biotehnologija u stočarstvu,13 (3-4),103-112

4. KOJIĆ M., SLAVICA MRFAT-VUKELIĆ, ZORA DAJIĆ, SUZANA ĐORĐEVIĆ-MILOŠEVIĆ: (2004):Livade i pašnjaci Srbije.Institut za istraživanja u poljoprivredi,Beograd

5. LAZAREVIĆ D., STOŠIĆ M., MRFAT-VUKELIĆ SLAVICA (1991): Dynamic of weed appearance in the meadow Danthonietum calycinae association in dependence of the wey of fertilization. Proceedings EGF symposium "Grassland renovation and weed control in Europe", Graz, Austria, 77-78

6. LAZAREVIĆ D., STOŠIĆ M., PAVEŠIĆ-POPOVIĆ JASNA (1995): Dynamics of production of natural grassland Danthonietum calycinae in Mt. Kopaonik (Serbia). Review of research work at the Faculty of agriculture, $1,85-92$

7. LAZAREVIC D.(196):Dynamics of production and quality of natural grassland in different systems of utilization.Review of Research Work at the Faculty of Agriculture,Vol.41,No2,21-38

8. LAZAREVIĆ D., STOŠIĆ M., DINIĆ B., LUGIC Z. (1996): Production of natural grassland in different systems of utilization. Proceedings $16^{\text {th }}$ EGF meeting Grassland and land use systems, Grado, Italy, 483-488

9. MIJATOVIĆ M., RADOJEVIĆ D., ŠOŠIĆ S.(1968):Uticaj mineralnih đubriva na produktivnost i floristički sastav pašnjaka Agrostietum vulgarae, Zbornik naučnih radova,sv.II i III, Kruševac,65-76 
10. MIJATOVIĆ M., PAVEŠIĆ-POPOVIĆ JASNA (1972):Uticaj vremena unošenja NPK mineralnih đubriva na prinos tipova brdskih livada Agrostietum vulgaris i Chrysopogonetum grylli.Arhiv za poljoprivredne nauke,sv.91,84-96

11. MRFAT-VUKELIĆ SLAVICA, KOJIĆ M., STOŠIĆ M. (1992): Uticaj mineralnih đubriva na promene florističkog sastava i potiskivanje korova u as. Festuco-Agrostetum (Ht 91951) 1962 et Trinajstić na Kopaoniku. Acta herbologica, 2, 171-179

12. MRFAT-VUKELIĆ SLAVICA, STOŠIĆ M., TOMIĆ Z., SOKOLOVIĆ D. (1997): Florobiodiversity of meadow community Lolio-Cynosuretum cristati on Sjenica - Pester plateau (Serbia) in different nutrition conditions. Management for grassland biodiversity. Proceedings of the International occasional symposium of the European Grassland Federation, Warszawa, 155-158

13. RATH M., PEEL S.(2005):Grassland in Ireland and the UK.In:Grassland:a global resource,XX IGC, $13-27$

14. STOŠIĆ M. (1972): Uticaj mineralnih đubriva na botanički sastav i produktivnost livada tipa Danthonietum calycinae na Sjeničko-pešterskoj visoravni. Arhiv za poljoprivredne nauke, 91, 97-106

15. STOŠIĆ M. (1974): Uticaj mineralnih đubriva na prinos i floristički sastav brdske livade tipa Danthonietum calycinae. Arhiv za poljoprivredne nauke, 97, 121-147

16. STOŠIĆ M., RADOJEVIĆ D., MLADENOVIĆ R. (1974): Proučavanje uticaja fosfata različite rastvorljivosti $u$ kompleksnim đubrivima $i$ vremena primene na produktivnost prirodne livade. Agrohemija, 7-8, 251-262

17. STOŠIĆ M., MRFAT-VUKELIĆ SLAVICA, KOJIĆ M. (1989): The influence of environment and fertilizers on the yield and floristic composition of grasslands in Serbia. Proceedings XVI international grassland congress, Nice, 1449-1450

18. STOŠIĆ M., LAZAREVIĆ D., TOMIĆ ZORICA, DINIĆ B. (1996a): Investigation on the effect of the time and nitrogen fertiliser appllication pattern on the production dynamics and quality in grassland of the Festuceto - Agrostietum type in the mountain Kopaonik. J. Sci. Agric. Res., 203, 79-87

19. STOŠIĆ M., LAZAREVIĆ D., DINIĆ B. (1996b): Uticaj vremena iskorišćavanja i načina primene azotnog đubriva na raspored produkcije prirodnog travnjaka tipa Agrostetium vulgaris na Kopaoniku. Zbornik radova Instituta za ratarstvo i povrtarstvo, 26, 309-316

20. STOŠIĆ M., LAZAREVIĆ D., DINIĆ B., LUGIĆ Z. (1996): Uticaj prihranjivanja azotom na raspored prinosa travnjaka u različitim meteorološkim uslovima. Zbornik izvoda internacionalnog simpozijuma Suša i biljna proizvodnja, Lepenski Vir, 197

21. STOŠIĆ, M., SLAVICA MRFAT-VUKELIĆ, LAZAREVIĆ, D. (1999): Effects of fertilizers on floristic and production shanges in Ass. Danthonietum calycinae at different locations of hilly mountain regions of Serbia. Journal of Mountain Agriculture on the Balcans. Vol. 2, No. 2, 178-187

22. STOŠIĆ, M., SLAVICA MRFAT-VUKELIĆ, LAZAREVIĆ, D. (1999): Effects of different fertiliser rates and cutting dates on grassland production and shrub population on Mt. Kopaonik, Serbia. International Occasional Symposium of the EGF "Grasslands and Woody Plants in Europe. Thessaloniki, Greece

23. STOŠIĆ M., LAZAREVIĆ D., TERZIĆ D., SIMIĆ A.(2004): Uloga fosfora u proizvodnji stočne hrane na travnjacima. Acta Agriculturae Serbica. Vol.IX, 17. (Special Issue) 263-272. 